\title{
Kasus mastitis sub klinis pada sapi perah laktasi di Kecamatan Pujon Kabupaten Malang
}

\section{Sub clinical mastitis cases in Pujon sub-district, Malang regency}

\author{
Lili Zalizar*, Sujono, Dian Indratmi, Yovi A Soedarsono
}

\author{
Fakultas Pertanian dan Peternakan, Universitas Muhammadiyah Malang
}

Submitted : 09 September 2017, Accepted : 03 January 2018

\begin{abstract}
ABSTRAK : Penelitian ini bertujuan untuk megetahui jumlah kasus mastitis subklinis di Kecamatan Pujon, Kabupaten Malang. Penelitian ini dilakukan di Kabupaten Pujon Kabupaten Malang dengan menggunakan metode survei. Kriteria peternak yang dipilih minimal sudah 2 (dua) tahun memelihara sapi perah. Sebanyak 110 ekor sapi perah laktasi dari Dusun Maron Sebaluh Desa Pandesari dan 103 ekor sapi perah Dusun Bakir di Desa Sukomulyo diperiksa terhadap mastitis subklinis dengan menggunakan Uji Mastitis California (CMT). Selain itu, pengamatan langsung terhadap perawatan pasca pemerahan dan kepemilikan digester biogas dan juga wawancara menggunakan kuesioner dilakukan untuk mendukung data. Data dianalisis secara deskriptif dan statistik sederhana. Hasil penelitian menunjukkan bahwa pada Maron Sebaluh persentase sapi dengan mastitis subklinis mencapai $58,18 \%, 10,00 \%$ mastitis klinis dan 31,82\% negatif. Sedangkan di Bakir, mastitis subklinis mencapai $59,22 \%$, mastitis klinis $0,97 \%$ dan $39,81 \%$ negatif. Jumlah sapi yang menderita mastitis (subklinis dan klinis) dan mendapat pengobatan pencelupan pasca-pemerahan dengan antiseptik hanya 28 ekor sapi, lebih sedikit daripada yang hanya dibilas dengan air yang mencapai 107 ekor sapi. Kepemilikan digester biogas tidak akan secara otomatis mengurangi kasus mastitis karena perilaku petani dalam menjaga kebersihan kandang tidak terjaga. Setiap posisi puting sapi berisiko terinfeksi mikroorganisme yang menyebabkan mastitis.
\end{abstract}

Kata kunci: Mastitis, Subklinis, Pujon, Kabupaten Malang

ABSTRACT: The purpose of this research was to find out how much cases of subclinical mastitis in Pujon district, Malang regency. This research was conducted in Pujon District of Malang Regency by using survey method. The inclusion criteria of farmers is minimum 2 (two) years of dairy cows. As many as 110 heads of lactation dairy cows from Maron Sebaluh hamlet in Pandesari village and 103 heads of Bakir hamlet in Sukomulyo village were examined against mastitis by using California Mastitis Test (CMT). In addition, direct observation of post-milking treatment and ownership of biogas digesters and as well as interviews using questionnaires was conducted to support data. Data were analyzed descriptively and by using simple statistics. The results showed that in Maron Sebaluh the percentage of cows with subclinical mastitis reached $58.18 \%, 10.00 \%$ of clinical mastitis and $31.82 \%$ negative. Whereas in Bakir, subclinical mastitis reached $59.22 \%$, clinical mastitis $0.97 \%$ and $39.81 \%$ negative. The number of cows that suffered from mastitis (subclinical and clinical) and got the treatment of dipping post-milking with antiseptic is only 28 cows, fewer than that treated with rinse water, 107 cows. Ownership of biogas digester will not automatically reduce the case of mastitis since the behaviour of farmers in keeping barn hygiene is not maintained. Every position of cow's teat have risk to be infected by microorganisms that caused mastitis.

Keywords: Mastitis, Sub clinical, Pujon, Malang District

\section{PENDAHULUAN}

Penyakit radang kelenjar susu yang dikenal sebagai mastitis, merupakan masalah utama dalam tata laksana usaha

*Corresponding author: lilizalizar62@gmail.com

DOI: 10.21776/ub.jiip.2018.028.01.03 
peternakan sapi perah yang sangat merugikan, Mastitis adalah penyakit yang merupakan masalah di seluruh dunia yang mengakibatkan kerugian yang besar pada peternakan sapi perah akibat kualitas susu yang buruk, penurunan produksi susu, peningkatan biaya obat dan pelayanan dokter hewan,tingginya jumlah ternak yang diafkir sebelum waktunya dan kadangkadang terjadi kematian akibat penyakit tersebut (Kumar et al., 2010).

Penyebab utama mastitis pada sapi adalah bakteri Str.agalactiae, Str.dysgalactiae, $\quad$ S.uberis, $\quad$ Str zooepidermicus. Bakteri lain yang dapat menyebabkan mastitis adalah Escherichia coli (E.coli), E.feundeii, Aerobacter aerugenes dan Klebsiella pneumoniae (Subronto, 2008). Hasil penelitian GrAhn YT et.al (2004), menunjukkan sapi perah yang mendapatkan infeksi Streptococcus spp., S. aureus, A. pyogenes, E. coli, dan Klebsiella spp. menunjukkan penurunan produksi susu yang paling tinggi. Selain itu terjadi penurunan kualitas hasil olahan susu,peningkatan biaya perawatan dan pengobatan serta pengafkiran ternak lebih awal (Shim et al., 2004). Mastitis adalah penyakit yang paling menghabiskan biaya dan mempengaruhi produksi sapi perah (Halasa et al., 2007).

Mastitis ada dua jenis yaitu mastitis dengan gejala klinis yang jelas (mastitis klinis) dan yang gejala klinisnya tidak nampak (subklinis). Mastitis subklinis adalah mastitis yang tidak menampakkan perubahan fisik pada ambing dan susu yang dihasilkan, tetapi menyebabkan penurunan produksi susu, ditemukannya mikroorganisme patogen dan terjadi perubahan komposisi susu. Kasus mastitis subklinis pada sapi perah di Indonesia sangat tinggi sampai akhir 2006 mencapai 75-83\% menyebabkan kerugian yang besar (Sudarwanto et al., 2006). Demikian juga menurut Anderson et al. (2010), mastitis subklinis lebih umum terjadi daripada mastitis klinis. Kerugian terjadi akibat adanya kerusakan pada sel-sel epitel penghasil air susu dan jaringan ikat diantara sel-sel tersebut yang menyebabkan kapasitas produksi terus menurun secara permanen.

Dalam menghadapi mastitis, umumnya peternak menggunakan antibiotik. Namun dari beberapa laporan diketahui bahwa penggunaan antibiotik yang kurang tepat pada sapi perah menimbulkan residu dalam air susu yang dikonsumsi manusia, terjadinya reaksi alergi dan adanya kasus resistensi terhadap antibiotik dan menurunkan kualitas produk olahan susu. Menurut Sudarwanto et al., (1992) di wilayah Jakarta, Bogor dan Bandung menunjukkan bahwa 32,52 persen susu pasteurisasi posistif mengandung residu antibiotik dalam jumlah yang cukup tinggi.

Masalah lain dalam penanganan mastitis dengan antibiotik adalah penggunaan antibiotik secara luas di peternakan sapi perah telah menyebabkan terjadinya resistensi bakteri terhadap antibiotik (Wahyuni et al., 2005). Menurut hasil penelitian Aslantas dan Demir (2016), bakteri penyebab mastitis seperti Staphylococcus aureus resisten terutama pada antibiotika golongan $\beta$-lactam (contohnya antara lain penisilin dan sefalosporin). Selain itu juga resisten terhadap antibiotika golongan tetrasiklin dan eritromisin dalam tingkatan yang lebih rendah.

Dalam upaya untuk mencegah terjadinya mastitis, peternak melakukan manajemen pencegahan penyakit meliputi menjaga kebersihan kandang, menyalurkan kotoran ternak ke digester biogas dan melakukan dipping (pencelupan ambing pasca memerah ke dalam larutan 
antiseptik). Untuk mengetahui pengaruh manajemen pencegahan mastitis yang dilakukan peternak terhadap kasus mastitis maka dilakukan penelitian survei di daerah Pujon sebagai salah satu sentra peternak sapi perah di Jawa Timur.

\section{MATERI DAN METODE}

Penelitian ini menggunakan metode survei.Pengambilan sampel peternak berdasarkan kriteria minimal sudah 2 (dua) tahun beternak sapi pe-rah.Sebanyak 110 (seratus sepuluh ekor) sapi perah yang sedang laktasi dari Dusun Maron Sebaluh Desa Pandesari dan 103 (seratus tiga ekor) sapi perah laktasi dari Dusun Bakir Desa Sukomolyo diperiksa terhadap mastitis menggunakan uji California Mastitis Test/CMT (Sudarwanto, 1999). Selain itu dilakukan pengamatan langsung terhadap perlakuan pasca pemerahan dan kebersihan kandang serta wawancara untuk mendukung data.Data dianalisis secara deskriptif dan statistik sederhana.

\section{HASIL DAN PEMBAHASAN}

Pada Tabel 1, terlihat bahwa persentase jumlah sapi yang menderita mastitis subklinis jauh lebih besar daripada yang menderita mastitis klinis. Di Dusun Maron Sebaluh persentase sapi yang menderita mastitis subklinis mencapai $58,18 \%$, yang klinis mencapai $10 \%$ dan negatif mastitis $31,82 \%$. Sedangkan di Desa Bakir mastitis subklinis mencapai 59,22\%, yang klinis $0,97 \%$ dan negatif mastitis $39,81 \%$. Hal ini seperti laporan Sudarwanto et al., (2006), di Indonesia kasus mastitis subklinis sampai akhir tahun 2006 mencapai sekitar 75-83\%.

Tabel 1. Persentasi sapi yang menderita mastitis (\%)

\begin{tabular}{llllll}
\hline \multirow{2}{*}{ No } & Nama & \multicolumn{1}{c}{ Jumlah } & \multicolumn{3}{c}{ Kasus Mastitis (\%) } \\
\cline { 5 - 6 } & Lokasi & sampel (ekor) & Subklinis & \multicolumn{1}{c}{ Klinis } & Negatif \\
\hline 1 & Maron & 110 & $64(58.18)$ & $11(10,00)$ & $35(31,82)$ \\
& Sebaluh & & & & $41(39,81)$ \\
\hline 2 & Bakir & 103 & $61(59,22)$ & $1(0,97)$ & 410 \\
\hline
\end{tabular}

Hal yang membahayakan dari kasus mastitis subklinis adalah dari luar kelenjar susu tampak normal namun sebenarnya sudah terjadi infeksi mikroorganisme ke dalam kelenjar susu. Apabila peternak tidak mempunyai alat yang dapat mendeteksi adanya mastitis subklinis maka ternak tidak diberikan obat sehingga infeksi semakin berkembang dan akhirnya menjadi mastitis klinis. Apabila radang kelenjar susu tidak diobati maka pada akhirnya jaringan epitel yang terdapat pada kelenjar susu menjadi rusak dan tidak dapat menghasilkan air susu. Akibatnya produksi susu menurun atau tidak ber-henti, oleh karena itu di peternakan sapi perah perlu adanya program pencegahan terhadap mastitis. Salah satu upaya yang dilakukan adalah dengan pemeriksaan rutin mastitis. Menurut Sudarwanto dan Sudarnika (2008), salah satu metode pencegahan yang efektif pada mastitis subklinis adalah melalui pemeriksaan rutin setiap bulan pada periode laktasi normal.

Pada Tabel 1 juga terlihat bahwa persentase yang negatif mastitis cukup besar yaitu 31,82 persen di Dusun Maron Sebaluh dan 39,81 persen di Dusun Bakir. Hal ini kemungkinan sejumlah peternak di kedua lokasi tersebut sudah melakukan tindakan pencegahan terhadap mastitis antara lain dengan pencelupan puting (teat dipping) setelah pemerahan (lihat Tabel 2). 
Tabel 2. Kasus mastitis dan perlakuan peternak setelah pemerahan

\begin{tabular}{ccccc}
\hline \multirow{2}{*}{ No } & \multirow{2}{*}{ Nama Lokasi } & Jenis & \multicolumn{2}{c}{ Perlakuan setelah pemerahan } \\
\cline { 3 - 5 } & Mastitis & $\begin{array}{c}\text { Dipping dengan } \\
\text { antiseptik (ekor) }\end{array}$ & $\begin{array}{c}\text { Dibilas dengan } \\
\text { air (ekor) }\end{array}$ \\
\hline \multirow{2}{*}{1} & Maron Sebaluh & Subklinis & 7 & 57 \\
& & Klinis & 3 & 8 \\
& & Negatif & 12 & 23 \\
& \multirow{2}{*}{ Bakir } & Subklinis & 18 & 43 \\
& & Klinis & 0 & 1 \\
& & Negatif & 19 & 22 \\
\hline
\end{tabular}

Peternakan sapi perah rakyat di Kecamatan Pujon ada yang memberikan per-lakuan setelah pemerahan dengan antiseptik setiap pagi dan sore. Pada Tabel 2, jumlah kasus mastitis subklinis lebih sedikit terjadi pada sapi yang mendapat pencelupan puting (teat dipping) dengan antiseptik dibandingkan dengan perlakuan dibilas dengan air. Jumlah sapi yang menderita mastitis (subklinis dan klinis) dan mendapatkan perlakuan teat dipping pasca pemerahan dengan antiseptik sebanyak 28 ekor, sedangkan kasus mastitis yang mendapat perlakuan dibilas air sebanyak 109 ekor sapi. Antiseptik yang umum digunakan di lokasi tersebut mengandung senyawa Povidone iodine yang dapat menghambat pertumbuhan mikroorganisme.

Menurut Mahardika (2016), perlakuan teat dipping menurunkan jumlah sel somatik pada air susu sapi perah. Sel somatik di dalam air susu terutama terdiri dari leukosit dan beberapa dari sel epitel. Peningkatan jumlah sel somatik di dalam air susu menunjukkan adanya gangguan di dalam kelenjar susu terutama peradangan pada kelenjar susu akibat infeksi mikroorganisme atau mastitis. Menurut Sudarwanto (1999), indikator penting untuk mendiagnosis adanya mastitis yaitu meningkatnya jumlah sel somatik di dalam air susu. Untuk menghitung jumlah sel somatik dapat dilakukan dengan metode langsung misalnya Breed atau secara tidak langsung dengan menggunakan alat California Mastitis Test (CMT) yang digunakan dalam penelitian ini.

Teat dipping selain dapat menggunakan antiseptik kimia juga bisa menggunakan ekstrak dari tanaman obat. Beberapa tanaman telah diketahui mempunyai aktivitas antibakteri sehingga bisa digunakan untuk teat dipping. Hasil penelitian Kurniawan, Sarwiyono dan Surjowardojo (2013) menggunakan dekok daun kersen (Muntingia calabura L) dengan konsentrasi 20\% memiliki kemampuan menurunkan tingkat kejadian mastitis sebesar $80 \%$. Hasil penelitian Zalizar, Sujono dan Suyatno (2009), hasil uji invitro sediaan minyak bawang putih (garlic oil), ekstrak meniran dan salep daun sirih dapat menghambat pertumbuhan bakteri Staphylococcus aureus dan Escherichia coli. Bawang putih memiliki aktivitas antiperadangan dengan menurunkan kadar TNF-a (Ziamajidi dkk, 2017). Tanaman lain yang berpo-tensi dikembangkan sebagai anti mastitis adalah Phyllathus sp atau meniran. Zalizar (2013), membuktikan bahwa senyawa Flavonoid Phylantus niruri dapat meningkatkan kekebalan tikus terhadap infeksi bakteri penyebab mastitis Streptococcus agalactiae. Penelitian tersebut mendukung pendapat Amirghofran et al (2000) bahwa meniran selain sebagai antibakteri juga sebagai imunomodulator. 
Tabel 3 menunjukkan pada peternak di Dusun Maron Sebaluh yang mempunyai digester biogas, sapi yang menderita mastitis lebih banyak ditemukan daripada sapi di peternak yang tidak mempunyai digester biogas. Kondisi yang berbeda terjadi di Dusun Bakir Desa Sukomulyo, sapi yang menderita mastitis di peternak yang mempunyai digester biogas lebih sedikit daripada yang tidak mempunyai digester biogas. Perbedaan antara kedua tempat tersebut akibat adanya perbedaan perilaku. Apabila kotoran ternak cara dimasukkan ke dalam digester biogas sebenarnya dapat menurunkan peluang terjadinya kontaminasi lingkungan dengan mikroba patogen seperti bakteri Escherichia coli (Tulayakul et al., 2011; Zalizar et.al., 2013), namun karena faktor perilaku peternak yang tidak segera memasukkan kotoran ternak tersebut ke dalam digester biogas dengan cara mendorong masuk ke saluran yang menuju digester tersebut maka kotoran ternak menjadi lebih lama berada di dalam kandang. Hal inilah yang menyebabkan ternak sapi mudah terinfeksi oleh bakteri penyebab mastitis. Dalam hal ini perilaku peternak di Dusun Bakir lebih baik daripada di Dusun Maron Sebaluh.

Tabel 3. Mastitis pada sapi perah dan kepemilikan digester biogas

\begin{tabular}{|c|c|c|c|c|}
\hline \multirow{2}{*}{ No } & \multirow{2}{*}{ Nama Lokasi } & \multirow{2}{*}{ Jenis Mastitis } & \multicolumn{2}{|c|}{ Kepemilikan Digester Biogas } \\
\hline & & & Ada & Tidak ada \\
\hline \multirow[t]{3}{*}{1} & Maron Sebaluh & Subklinis & 46 & 18 \\
\hline & & Klinis & 7 & 4 \\
\hline & & Negatif & 30 & 5 \\
\hline \multirow[t]{3}{*}{2} & Bakir & Subklinis & 25 & 36 \\
\hline & & Klinis & 0 & 1 \\
\hline & & Negatif & 26 & 15 \\
\hline
\end{tabular}

Pada Tabel 4, terlihat bahwa pada posisi puting baik di depan atau belakang atau di kanan atau kiri semuanya beresiko terkena mastitis. Hal ini terlihat dari jumlah puting yang terkena mastitis hampir sama pada semua posisi.

Tabel 4. Kasus mastitis dan posisi puting yang terdeteksi positif

\begin{tabular}{ccccccc}
\hline \multirow{2}{*}{ No } & Nama & Jenis & \multicolumn{4}{c}{ Posisi puting } \\
\cline { 4 - 7 } & Lokasi & Mastitis & $\begin{array}{c}\text { A } \\
\text { (depan } \\
\text { kanan) }\end{array}$ & $\begin{array}{c}\text { B } \\
\text { (depan } \\
\text { kiri) }\end{array}$ & $\begin{array}{c}\text { C } \\
\text { (belakang } \\
\text { kanan) }\end{array}$ & $\begin{array}{c}\text { D } \\
\text { (belakang } \\
\text { kiri) }\end{array}$ \\
\hline \multirow{2}{*}{1} & Maron & Subklinis & 34 & 36 & 45 & 37 \\
& Sebaluh & Klinis & 5 & 6 & 3 & 4 \\
& & Negatif & 71 & 68 & 62 & 69 \\
& & & & & & \\
& \multirow{2}{*}{ Bakir } & Subklinis & 32 & 28 & 30 & 31 \\
& & Klinis & 1 & 0 & 0 & 0 \\
& & Negatif & 70 & 75 & 73 & 72 \\
\hline
\end{tabular}


Pada peternakan sapi perah rakyat di Kecamatan Pujon Kabupaten Malang khususnya di Dusun Maron Sebaluh Desa Pandesari dan Dusun Bakir Desa Sukomulyo, kasus mastitis subklinis lebih tinggi daripada mastitis klinis. Di Dusun Maron Sebaluh persentase sapi yang menderita mastitis subklinis mencapai $58,18 \%$, yang klinis mencapai $10,00 \%$ dan negatif mastitis $31,82 \%$. Sedangkan di Desa Bakir mastitis subklinis mencapai 59,22\%, yang klinis $0,97 \%$ dan negatif mastitis $39,81 \%$. Jumlah sapi yang menderita mastitis (subklinis dan klinis) dan mendapatkan perlakuan teat dipping pasca pemerahan dengan antiseptik sebanyak 28 ekor, lebih sedikit dibandingkan yang mendapat perlakuan dibilas air sebanyak 107 ekor sapi. Kepemilikan digester biogas tidak otomatis akan menurunkan kasus mastitis selama perilaku peternak dalam menjaga kebersihan kandang tidak dijaga. Semua posisi puting beresiko terkena mastitis.

\section{DAFTAR PUSTAKA}

Amirghofran Z, M Azad baktit and M.H.Karimi. 2000. Evaluation of the Immunomodulatorry effect of five herbal plants. Journal of Etnopharmacology,72: 167-172

Aslantaş O and C Demir. 2016. Investigation of the antibiotic resistance and biofilm-forming ability of Staphylococcus aureus from subclinical bovine mastitis cases J. Dairy Sci. 99:1-7. http://dx.doi.org/10.3168/jds.201611310

Andersen, S., Dohoo, I., Olde Riekerink, R., Stryhn, H., 2010. Diagnosing intramammary infections: Evaluating expert opinions on the definition of 421 intramammary infection using conjoint analysis. Journal of Dairy Science 93, 29662975

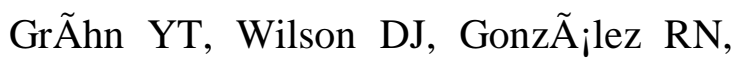
Hertl JA, Schulte H, Bennett G, Schukken YH. 2004. Effect of pathogen-specific clinical mastitis on milk yield in dairy cows. J Dairy Sci. 2004 Oct;87(10):3358-74.

Halasa, T., Huijps, K., Østerås, O., Hogeveen, H., 2007. Economic effects of bovine 457 mastitis and mastitis management: A review. Veterinary Quarterly 29, 18-31.

Kurniawan I, Sarwiyono, P Surjowardojo. 2013. Pengaruh teat dipping menggunakan dekok daun kersen (Muntingia calabura L.) terhadap tingkat kejadian mastitis Jurnal Ilmu-Ilmu Peternakan 23 (3): 27 31

Kumar, R., B. R. Yadav, and R. S. Singh. 2010. Genetic determinants of antibiotic resistance in Staphylococcus aureus isolates from milk of mastitic crossbred cattle. Curr. Microbiol. 60:379-386.

Mahardika HA. 2016. Pengaruh suhu air pencucian ambing dan teat dipping terhadap jumlah produksi, kualitas dan jumlah sel somatik susu pada peternakan sapi peranakan Fresian Holstein. Buletin Peternakan Vol 40 (1):11-19

Shim, E. H., R. D. Shanks \& D. E. Morin. 2004. Milk loss and treatment costs associated with two treatment protocols for clinical mastitis in 
dairy cows. J. Dairy Science 87: 2702-2708.

Sudarwanto, M., W. Sanjaya, dan P. Trioso. 1992. Residu antibiotika dalam susu pasteurisasi ditinjau dari kesehatan masyarakat. Jurnal Ilmu Pertanian Indonesia 2(1): 37-40.

Sudarwanto,M. 1999. Usaha Peningkatan Produksi Susu Melalui Program Pengendalian Mastitis Subklinis. Orasi Ilmiah, 22 Mei 1999.Fakultas Kedokteran Hewan. Institut Pertanian Bogor.

Sudarwanto, M., H. Latif \& M. Noordin. 2006.The relationship of the somatic cell counting to sub-clinical mastitis and to improve milk Quality. 1st International AAVS Scientific Conference. Jakarta, July 12-13, 2006.

Sudarwanto,M. and E.Sudarnika 2008. Hubungan antara $\mathrm{pH}$ Susu dengan Jumlah Sel Somatik Sebagai Parameter Mastitis Subklinik.Media Peternakan. Agustus 2008, Vol. 31( 2): 107-113

Subronto. 2008. Ilmu Penyakit Ternak. $\begin{array}{lrr}\text { (Mammalia). } & \text { Edisi } & \text { ke- } \\ \text { 3.Yogyakarta: } & \text { Gadjah } & \text { Mada } \\ \text { University Press. } & & \end{array}$

Wahyuni AETH dan IW Wibawan, MH Wibowo. 2005. Karakterisasi Hemaglutinin Streptococcus agalactiae dan Staphylococcus aureus Penyebab Mastitis Subklinis Pada Sapi Perah. J Sain Vet. 23:25

Tulayakul P., Alongkot Boonsoongnern, S. Kasemsuwan, S. Wiriyarampa,J.
Pankumnoed, S. Tippayaluck, H. Hananantachai, Ratchaneekorn Mingkhwan, R. Netvichian, S. Khaodhiar. 2011. Comparative study of heavymetal and pathogenic bacterial contamination in sludge and manure in biogas and nonbiogas swine farms. J. Environ. Sci. 2011, 23(6) 991-997

Zalizar L. 2013. Flavonoids of Phylanthus Niruri as Immunomodulators.A Prospect to Animal Disease Control. ARPN Journal of Science and Technology Vol. 3 (5):529-532

Zalizar L, R Relawati, B Yudi Ariandi. 2013. Potensi produksi dan ekonomi biogas serta implikasinya pada kesehatan manusia, ternak dan lingkungan. Jurnal Ilmu-Ilmu Peternakan 23 (3): $32-40$

Zalizar L, Sujono dan Suyatno. 2015. Daya Antibakteri Salep Herbal (Piper Betle Dan Phyllanthus Niruri terhadap Bakteri Staphylococcus aureus dan Escherichia coli. Laporan Penelitian Block Grant. Fakultas Pertanian-Peternakan. Universitas Muhammadiyah Malang.

Ziamajidi N, Nasiri A, Abbasalipourkabir R \& Moheb SS. 2017. Effects of garlic extract on TNF- $\alpha$ expression and oxidative stress status in the kidneys of rats with $\mathrm{STZ}+$ nicotinamideinduced diabetes. Pharmaceutical Biology, 55:1, 526-531, DOI: 10.1080/13880209.2016.1255978. 